\title{
The Bleye Kukum of South Upi: The Justice System on Conflict Resolution
}

DOI: https://doi.org/10.47175/rissj.v3i1.352

\section{| Tahir K. Salipada ${ }^{1}$ | Datuali P. Abdula ${ }^{2}$ | Marop A. Kanakan³ |}

${ }^{1}$ Mindanao State UniversityMaguindanao, Maguindanao, Philippines

${ }^{2}$ Mindanao State UniversityMaguindanao, Maguindanao, Philippines

${ }^{3}$ Community Facilitator, Ministry of Social Services and Development, Philippines

${ }^{1}$ tksalipada@msumaguindanao .edu.ph

²dpabdula@msumaguindanao. edu.ph

\begin{abstract}
This study aimed to assess the level of effectiveness of the implementation of the Bleye Kukum justice system in terms of: Conflict resolution, Peace and Order, Governance, and Economy was also identified. Also, the problems encountered by the Indigenous People concerning the Bleye Kukum justice system, which was the basis of the policy recommendations. The study used the descriptive-evaluative method to determine the level of effectiveness of the implementation of the Bleye Kukum justice system in South Upi, Maguindanao. It was conducted in the selected barangays in the municipality of South Upi, Maguindanao. The respondents of this study were the Tri-People (Muslim, Christian and Teduray) living in the selected barangays which are Barangay Romongaob and Barangay Kuya with the total of One Hundred (100) respondents. The findings show that the respondents' profile revealed that in terms of the profile of the respondents, most of the respondents were belong to the age of 30 to 39, married, female, earning of 3,000 and below per month, with a big number of dependents and have elementary level of educational attainment. In the level of effectiveness of the implementation of the Bleye Kukum Justice System in terms of conflict resolution, peace and order, governance and economy were considered as effective. Majority of the respondents experienced problem on the Bleye Kukum's process of settling. Thus, it is concluded that the level of effectiveness of the implementation of the Bleye Kukum Justice System is effective.

KEYWORDS

Bleye Kukum; justice system; conflict resolution
\end{abstract}

\section{INTRODUCTION}

The indigenous conflict resolution plays a very significant role in the day-to-day lives of many ethnic groups and tribes particularly the poor and marginalized societies. Local leaders and elderly people have used traditional laws to ensure conflict do not curve into uncontrolled violence and disrupt civic life (Alemie et al, 2018; Ragandang III, 2018; Maganag, 2019). Locally trusted elderly people enjoy socially eminent status and authority granted by customs while passing decisions are based on a high level of social consensus and legitimacy. The process is soft and based on the willingness of conflicting parties, the relationship between individuals, among families and kinship become strong. Indigenous conflict resolution system allows conflicting parties to work cooperatively by minimizing their gap in productive way that does not demolish their relationship. But solving conflicts or disagreements through formal process by using courts disputants rarely want to work together and cooperatively. Compared with that of the formal conflict resolution process, indigenous conflict resolution mechanisms take less time to dispose of a single case (Circular No. 14-93 July 15 1993). 
Justice system has always been part of every culture to resolve conflict, inequality and impartiality. It is an indispensable component of governance. We can see to our national government that it is composed of three branches and one of them is the judiciary that serves the justice system of the country. From it alone, we can say that the justice system is a must and it was influenced and evolved from the diverse cultures that the country has.

It is indicated in the history that Teduray, Dulangan Manobo and Maguindanaon have common ancestry until the coming of Islam in Mindanao estimated by many scholars that happened between 1450-1475AD. These people traced their roots from brothers Mamalu and Tabunaway who practiced one and the same tradition of self-rule, culture and economic activities whose title holders are called Baglalan under a Timuay system of governance. In addition, there was a council of local Moro or Maguindanaon, Teduray and 'Christian' leaders organized by the municipality's Teduray mayor to address and resolve local disputes in the area, which are one of the most serious problems faced by the people and the local government called the Bleye Kukum. It is where the justice system of Tri- people originated and had evolved throughout the course of time (Republic Act No. 8371).

The Executive Order number 1 of 2005 was amended and renamed the mayor's council as Bleye Kukum for the Municipality of South Upi, Maguindanao through Executive Order no. 16 series of 2016. It was created to help the Barangay Council and the parties involved, to amicably settle cases, disputes, conflicts, to avoid the rigors and detrimental effects of court litigants, and finally to help the government to minimize if not eradicate clogging of cases before the established courts. To facilitate the resolution of cases that have not been resolved at the barangay level. It is represented by various groups in South Upi and uses a combination of traditional and prevailing laws in settling conflicts. However, as a matter of procedure, the Bleye Kukum does not resolve cases that have not been heard before the barangay conflict resolution body. It is the experience in South Upi that cases are referred to the Bleye Kukum for mediation rather than to the local police.

Knowing how our ancestors served justice such as that continuous practiced the Tripeople in South Upi, Maguindanao in particular can serve as a guide on how we can improve our local and national justice system. It is in this context that the researcher deemed this study necessary.

There have continuing disputes between and among Tri-people in South Upi, Maguindanao that sometimes leads to life-threatening and risking lives of certain individuals. Many incidents like land disputes, confrontations, stealing, political rivalries, marital disputes and also a wide range of conflict from simple theft to estafa, slight physical injuries to frustrated murder or murder, other heinous crimes like rape, land conflict, and cases involving family relations, succession, and inheritance have been observed and experienced. Hence, the researcher would like to assess how effective the Bleye Kukum justice system is in settling or resolving this kind of conflict. Generally, this study aimed to assess the level of effectiveness of the Bleye Kukum justice system of Indigenous People at South Upi, Maguindanao during the fiscal year 2020-2021. Specifically, it sought answers to the following questions: What is the demographic profile of the respondents in terms of age; gender; civil status; income; a number of dependents; and educational attainment? What is the level of effectiveness of the Bleye Kukum justice system in terms of; conflict resolution; peace and order; governance; and economy? What are the problems encountered by the Indigenous People concerning the Bleye Kukum justice system? What are the policy recommendations that can be drawn from the study? 


\section{RESEARCH METHODS}

The study used the descriptive-evaluative research design. The quantitative approach was employed to understand the perception and outlook of household heads about the implementation of Bleye Kukum in terms of Conflict Resolution, Peace and Order, Governance and Economy in their local area using semi-structured questionnaires. And, it employed to grasp the attitude of respondents regarding the level of effectiveness of the implementation of the Bleye Kukum justice system because using different research strategies in the same study to collect data is advantageous to ensure validity and reliability of the findings and to control possible data bias.

The respondents of this study were the Tri-people (Muslim, Christian and Teduray) who are living in Barangay Romongaob and Barangay Kuya, South Upi, Maguindanao. This study used three sampling procedures, purposive, quota sampling and simple random sampling. The purposive method was used to identify barangays as settings of the study using the following criteria; from the largest number of population, to the middle and to the least member of population while quota sampling was used to get the 100 sample respondents and in selecting the 100 respondents, simple or pure random sampling was used. From 100 household heads who have experienced/knowledge on indigenous conflict resolution systems in Bleye Kukum, the researcher took 50 (from from each Barangay) village residents by using a simple random sampling technique. Thus, the lists of household respondents were the sample frame of the study.

This study used a questionnaire as the major instrument used in the data collection. The research instrument was divided into two parts. The first part contains the demographic profile of the respondents need to fill all the needed information. The second part is a checklist of information on the given questions where the respondents need to put a check on the given frequency whether it is Very Effective, Effective, Less Effective and Not Effective. This is needed in this study to take into consideration the beneficiaries' personal information on the implementation of Bleye Kukum Justice System.

\section{RESULTS AND DISCUSSION}

\section{Demographic Profile of the Respondents}

The Demographic profile of the respondents in the study included their age, gender, civil status, income, number of dependents and educational attainment. These profile characteristics were included in the study to distinguish the participants and support the result of the study.

Table 1 reveals the results of the respondent's profile. In terms of age, majority of the respondents were belong to the age bracket of 30-39 with 32 percent. There were 23 or 23 percent of the respondents belong to the age bracket of 20-29, 16 respondents from the age bracket of 40-49, 12 respondents belong to age bracket of 50-59, 11 respondents belong to less than 20 of age and there were 6 respondents belong to the age of 60 and above. These imply that the respondents are matured enough to face the justice system conflict resolution.

On the other hand, in terms of gender there were $73 \%$ female and $27 \%$ male. In terms of civil status there were $73 \%$ married, $18 \%$ single, $5 \%$ separated and $4 \%$ widowed/er. This implies that majority of the respondents are married.

Based on the table, majority of the respondents earned 3,000 and below per month with $78 \% .15 \%$ earned 3,001 to 8,000 monthly while 7\% earned 8,001 and above per month. 
Table 1. Profile of the Respondents $(n=100)$

\begin{tabular}{|c|c|c|c|}
\hline Variable & & $\mathbf{f}$ & $\mathrm{f} \%$ \\
\hline \multirow[t]{6}{*}{ Age } & Less than 20 & 11 & 11.0 \\
\hline & 20 to 29 & 23 & 23.0 \\
\hline & 30 to 39 & 32 & 32.0 \\
\hline & 40 to 49 & 16 & 16.0 \\
\hline & 50 to 59 & 12 & 12.0 \\
\hline & 60 and Above & 6 & 6.0 \\
\hline \multirow[t]{4}{*}{ Gender } & Male & 27 & 27.0 \\
\hline & Female & 73 & 73.0 \\
\hline & Mean & & \\
\hline & Standard Deviation & & \\
\hline \multirow[t]{3}{*}{ Civil Status } & Single & 18 & 18.0 \\
\hline & Married & 73 & 73.0 \\
\hline & Separated & 5 & 5.0 \\
\hline \multirow{4}{*}{ Income } & Widowed/er & 4 & 4.0 \\
\hline & $\mathrm{P} 3,000$ and Below/month & 78 & 78.0 \\
\hline & $\mathrm{P} 3,000$ to $\mathrm{P} 8,000 /$ month & 15 & 15.0 \\
\hline & P8,001 and above/month & 7 & 7.0 \\
\hline \multirow[t]{3}{*}{ Number of Dependents } & $1-2$ members & 8 & 8.0 \\
\hline & 3-4 members & 41 & 41.0 \\
\hline & 5-12 members & 51 & 51.0 \\
\hline \multirow[t]{7}{*}{ Educational Attainment } & College Graduate & 11 & 11.0 \\
\hline & College Level & 3 & 3.0 \\
\hline & High School Graduate & 13 & 13.0 \\
\hline & High School Level & 21 & 21.0 \\
\hline & Elementary Graduate & 19 & 19.0 \\
\hline & Elementary Level & 32 & 32.0 \\
\hline & Vocational Course & 1 & 1.0 \\
\hline
\end{tabular}

In addition, majority of the respondents have large family. There were $51 \%$ who have 5 12 members. $41 \%$ respondents have medium-sized family as their family members range from three to four (3 to 4) members and eight (or 8\%) of the respondents who has small family size with one to two independent.

In terms of Educational attainment, there were 11 (or 11\%) respondents who graduated college, three (or 3\%) who reached the college level but not completed, 13 (or 13\%) of the respondents were high school graduates, 21 (or 21\%) have reached the high school level, 19 (or 19\%) were elementary graduates while $32 \%$ of the respondents or $32 \%$ reached the elementary level only and one (or $1 \%$ ) of the respondents took vocational course.

The data and information showed in general that Tri-people respondents used Bleye Kukum justice system due to low educational attainment. They have large number of dependents to feed of and most of them have no job. Only farming is the source of living that resulted to low income which they cannot able to pay for lawyers to assist and resolve their issues and concerns. 
The Level of Effectiveness of the Implementation of the Bleye Kukum Justice System

Conflict Resolution

Table 2. Distribution of Respondents' Perception on Conflict Resolution ( $\mathrm{n}=100)$

\begin{tabular}{|c|c|c|c|c|c|c|}
\hline \multirow{2}{*}{ Indicator } & \multicolumn{4}{|c|}{ Frequency } & \multirow{2}{*}{ Mean } & \multirow{2}{*}{ Description } \\
\hline & 4 & 3 & 2 & 1 & & \\
\hline $\begin{array}{l}\text { 1. The Bleye kukum justice system is essential in } \\
\text { settling ancestral land conflict }\end{array}$ & 45 & 32 & 14 & 9 & 3.13 & $\begin{array}{l}\text { Very } \\
\text { Effective }\end{array}$ \\
\hline $\begin{array}{l}\text { 2. The conflict resolution of Bleye kukum helps } \\
\text { Tri-people in political territory disputes }\end{array}$ & 34 & 44 & 17 & 5 & 3.07 & Effective \\
\hline $\begin{array}{l}\text { 3. The Bleye Kukum justice system is just and } \\
\text { fair regardless of cultural entity }\end{array}$ & 29 & 45 & 23 & 3 & 3.00 & Effective \\
\hline $\begin{array}{l}\text { 4. The Bleye Kukum is vital in restoring peace } \\
\text { and order }\end{array}$ & 33 & 38 & 25 & 4 & 3.00 & Effective \\
\hline Overall & 35.25 & 39.75 & 19.75 & 5.25 & 3.05 & Effective \\
\hline
\end{tabular}

Table 2 shows the summary of the mean on the perception of the respondents in terms of conflict resolution. The majority of the respondents agreed that the implementation of Bleye Kukum justice system in terms of conflict resolution is described as "Effective" with an overall mean of 3.05 .

Most of the issues pertaining to conflict resolution in general were resolved. Furthermore, most of the issues on ancestral land, political territory, cultural entity and peace and order were recognized and settled. Every tribe has equally represented in the Bleye Kukum justice system.

Specifically, statement number 1 "The Bleye Kukum justice system is essential in setting ancestral conflict." got the highest rating with a description of "Very Effective" with a mean of 3.13. This implies that it helps a lot in settling issues on ancestral land conflict and most of the raised concern pertaining to land conflict is gradually resolved. In statement number 2 "The conflict resolution of Bleye kukum helps Tri-people in political territory disputes." is the second highest rating with a description of "Effective" with a mean of 3.07.

\section{Peace and Order}

Table 3. Distribution of Respondents on their perception on Peace and Order. $(n=100)$

\begin{tabular}{|c|c|c|c|c|c|c|}
\hline \multirow{2}{*}{ Indicator } & \multicolumn{4}{|c|}{ Frequency } & \multirow{2}{*}{ Mean } & \multirow{2}{*}{ Description } \\
\hline & 4 & 3 & 2 & 1 & & \\
\hline $\begin{array}{l}\text { 1. The Bleye Kukum justice system is very useful } \\
\text { in settling political territorial conflict }\end{array}$ & 31 & 44 & 20 & 5 & 3.01 & Effective \\
\hline $\begin{array}{l}\text { 2. Bleye Kukum helps Tri- people in maintaining } \\
\text { lasting peace and development regardless of } \\
\text { cultural entity }\end{array}$ & 35 & 41 & 19 & 5 & 3.06 & Effective \\
\hline $\begin{array}{l}\text { 3. Bleye Kukum justice system is just and fair in } \\
\text { practicing and promoting cultural identity } \\
\text { through customary laws within their respective } \\
\text { territory }\end{array}$ & 32 & 53 & 11 & 4 & 3.13 & Effective \\
\hline $\begin{array}{l}\text { 4. Bleye Kukum is recognizing the Tri-people } \\
\text { political struggle }\end{array}$ & 24 & 62 & 10 & 4 & 3.06 & Effective \\
\hline Overall & 30.5 & 50 & 15 & 4.5 & 3.07 & Effective \\
\hline
\end{tabular}


Table 3 shows the summary of the mean on the perception of the respondents in terms of Peace and Order. In general, the respondents agreed that the implementation of Bleye Kukum justice system in terms of Peace and Order is "Effective" with an overall mean of 3.07 .

Specifically, statement number 3 "Bleye Kukum justice system is just and fair in practicing and promoting cultural identity through customary laws within their respective territory." got a highest rating with a description of "Effective" with a mean of 3.13. It is fairly practice and continuously promotes the cultural identity of these Tri-people within their respective territory. The bleye kukum also recognized the diverse customary laws of the Tri-people.

Hence, statement numbers 2 and 4 "Bleye Kukum helps Tri- people in maintaining lasting peace and development regardless of cultural entity." and "Bleye Kukum is recognizing the Tri-people political struggle." got the same description of effective with a mean3.06. It implies that the Bleye Kukum officers exert their efforts in coordinating and communicating these Tri-people towards maintaining lasting peace and development regardless of the cultural entity. This system support and recognized the potential of Tri-people in political struggle.

\section{Governance}

Table 4. Distribution of Respondents on their Perception on Governance $(n=100)$.

\begin{tabular}{|c|c|c|c|c|c|c|}
\hline \multirow{2}{*}{ Indicator } & \multicolumn{4}{|c|}{ Frequency } & \multirow{2}{*}{ Mean } & \multirow{2}{*}{ Description } \\
\hline & 4 & 3 & 2 & 1 & & \\
\hline $\begin{array}{l}\text { 1. The Bleye Kukum justice system is vital in } \\
\text { settling inequalities and Impartiality in } \\
\text { governance }\end{array}$ & 20 & 62 & 13 & 5 & 2.97 & Effective \\
\hline $\begin{array}{l}\text { 2. The Bleye Kukum helps Tri- people in } \\
\text { maintaining equal representation in all level of } \\
\text { governance including right to rule and govern }\end{array}$ & 29 & 58 & 7 & 6 & 3.10 & Effective \\
\hline $\begin{array}{l}\text { 3. The Bleye Kukum justice system is a just and } \\
\text { fair in practicing and promoting equal } \\
\text { opportunities and representation in all level of } \\
\text { governance }\end{array}$ & 30 & 53 & 12 & 5 & 3.08 & Effective \\
\hline $\begin{array}{l}\text { 4. Bleye Kukum is recognizing and respecting } \\
\text { vis-à-vis traditional and customary laws of Tri- } \\
\text { people }\end{array}$ & 41 & 49 & 7 & 3 & 3.28 & Effective \\
\hline Overall & 30 & 55.5 & 9.75 & 4.75 & 3.11 & Effective \\
\hline
\end{tabular}

The data shows the summary of the mean on the perception of the respondents in terms of Governance. In general, the respondents agreed that the implementation of Bleye Kukum justice system in terms of Governance is "Effective" with an overall mean of 3.11. This implies that the Bleye Kukum justice system always promotes equal representation of Tripeople in all levels of governance and opportunities. It also recognized the customary laws of the Tri-people.

Specifically, statement number 4 "Bleye Kukum is recognizing and respecting vis-à-vis traditional and customary laws of Tri-people." got a highest which describes as "Effective" with a mean of 3.28. It continuously promotes and recognizes customary laws of Tri-people within their respective territory. The Bleye Kukum also respect the diverse customary laws of the Tri-people.

Also, statement number 2 "The Bleye Kukum helps Tri- people in maintaining equal representation in all level of governance including right to rule and govern." was the second highest rating with a description of "Effective" and a mean of 3.10. This implies that the 
Bleye Kukum officers helped to promote and maintain equal representation in all levels of governance and opportunities for the Tri-people.

\section{Economy}

Table 5. Distribution of Respondents' Perception on Economy $(n=100)$.

\begin{tabular}{|c|c|c|c|c|c|c|}
\hline \multirow{2}{*}{ Indicator } & \multicolumn{4}{|c|}{ Frequency } & \multirow{2}{*}{ Mean } & \multirow{2}{*}{ Description } \\
\hline & 4 & 3 & 2 & 1 & & \\
\hline $\begin{array}{l}\text { 5. The Bleye Kukum justice system is very useful } \\
\text { in settling natural resources conflict }\end{array}$ & 26 & 47 & 24 & 3 & 2.96 & Effective \\
\hline $\begin{array}{l}\text { 6. Bleye Kukum helps Tri- people in maintaining } \\
\text { respect and upheld IP rights }\end{array}$ & 35 & 55 & 7 & 3 & 3.22 & Effective \\
\hline $\begin{array}{l}\text { 7. Bleye Kukum justice system is a just and fair } \\
\text { in promoting equitable share in all numeral } \\
\text { resources including strategic minerals and } \\
\text { forestry resources }\end{array}$ & 18 & 53 & 19 & 10 & 2.79 & Effective \\
\hline $\begin{array}{l}\text { 8. Bleye Kukum is respecting and upholding } \\
\text { rights of IPs in matters of exploitation and } \\
\text { exploration of natural resources that may find } \\
\text { within their ancestral domain areas }\end{array}$ & 35 & 51 & 10 & 4 & 3.17 & Effective \\
\hline Overall & 28.5 & 51.5 & 15 & 5 & 3.04 & Effective \\
\hline
\end{tabular}

On Table 5. the data shows the summary of the mean on the respondents' perception in terms of Economy. In general, the respondents agreed that the implementation of Bleye Kukum Justice System in terms of Economy is "Effective" with an overall mean of 3.04. This implies that the Bleye Kukum unendlessly helps, supports and promotes equitable share in all natural resources, equal treatment for job and opportunities and strongly condemned exploitation and discrimination regardless of cultural entity.

Specifically, statement number 2 "Bleye Kukum helps Tri- people in maintaining respect and upheld IP rights." got a highest rating with a description of "Effective" and a mean of 3.22. The Bleye Kukum continuously maintains respect, promotes and recognizes IP rights. It condemned and discouraged discrimination of cultural identity of each Tri-people.

Also, statement number 4 "Bleye Kukum is respecting and upholding rights of IPs in matters of exploitation and exploration of natural resources that may find within their ancestral domain areas." got the second highest rating with a description also of "Effective" with a mean of 3.17. It indicates that the Bleye Kukum officers helped to promote and maintain respect on the rights of IPs specifically exploitation and exploration of natural resources within their ancestral domain areas. It supports and helps to fight the rights of the IPs on ancestral domain and natural resources claims.

Table 6. Distribution of the Summary on the Level of Effectiveness of the Implementation of the Bleye Kukum Justice System.

\begin{tabular}{lll}
\hline Indicator & Mean & Description \\
\hline Conflict Resolution & 3.05 & Effective \\
Peace and Order & 3.07 & Effective \\
Governance & 3.11 & Effective \\
Economy & 3.04 & Effective \\
\hline Total & $\mathbf{3 . 0 7}$ & Effective \\
\hline
\end{tabular}

The Table 6 shows the summary of the mean with the overall responses of the respondents on the implementation of the Bleye Kukum Justice system in terms of Conflict Resolution, Peace and Order, Governance and Economy. In general, the respondents expressed that the implementation of the Bleye Kukum justice system is Effective with an overall mean of 3.07. 
Table 7. Problems Encountered in the Implementation of Bleye Kukum Justice System

\begin{tabular}{lrrl}
\multicolumn{1}{c}{$(\mathrm{n}=100)$} & & & \\
\hline Problems Encountered by the Tri-People on Bleye Kukum & Frequency & Percentage & Rank \\
Justice System & 81 & 81 & 1 \\
\hline 1. Bleye Kukum's process of settling conflict & 34 & 34 & 7.5 \\
2. Involvement of elected officials and officers in the dispute settlements & 42 & 42 & 4 \\
3. Response of Bleye Kukum officers on the raised conflicts & 47 & 47 & 2 \\
4. Participation and intervening of other parties on the settlements & 43 & 43 & 3 \\
5. Decision of Local chief executive on the conflict settlements & 41 & 41 & 5 \\
6. Changing of leaders that affect the overall implementation of Bleye Kukum & 37 & 37 & 6 \\
7. No proper turnover of files, documents or data from previous officers & 34 & 34 & 7.5 \\
8. Prejudices in selecting Bleye kukum officers & & &
\end{tabular}

Table 7 shows the problems encountered by the respondents. Majority of the respondents have experienced problems on Bleye Kukum's process of settling conflict with frequency of 81, followed by Participation and intervening of other parties on the settlements with 47 frequency and 43 frequency on the decision of Local chief executive on the conflict settlements.

In addition, the respondents experienced also the delayed processes of conflict settlements and sometimes ignored raised concerns due to unfollowed procedures and protocols on the settlements. The proper procedures and protocols on the settlements must start on the hearing at barangay level three times, if an issue was unsettled then it will bring up to Bleye Kukum bearing the minutes of meetings during hearing/s. The Bleye kukum will send an invitation letter to the concerned individuals until 3 times. The unsettled issues will be forwarded to court. It also affects the intervening and participation of other parties or affiliation in the process of settlements. And the decision of the Local chief executive is sometimes perceived as problems by the complainant.

\section{CONCLUSION}

Based on the summary of findings, it is concluded that the the Bleye Kukum Justice System implementation is effective.

\section{REFERENCES}

CIRCULAR NO. 14-93 July 151993 Guidelines on the Katarungang Pambarangay Conciliation Procedure to Prevent Circumvention of the Revised Katarungang Pambarangay Law (Sections 399-422, Chapter VII, Title I, Book III, R.A. 7160. Otherwise Known as the Local Government Code of 1991).

EXECUTIVE ORDER: 11 Series of 2016 amending Executive Order number 1 of 2005 and renaming the Mayor's Council as Bleye Kukum for the Municipality of South Upi, Maguindanao

Republic Act No. 8371, Otherwise Known As “The Indigenous Peoples' Rights Act Of 1997” National Commission on Indigenous Peoples Administrative Order No. 1 Rules and Regulations Implementing

Alemie, Ajanaw and Mandefro, Hone (2018). Roles of Indigenous Conflict Resolution Mechanisms for Maintaining Social Solidarity and Strengthening Communities in Alefa District, North West of Ethiopia https://journalhosting.ucalgary.ca/index.php/jisd/article/view/58481

Maganag, Edgar M. (2019) Conflict Resolution Management of the Indigenous People Of Upland Kalinga, Northern Philippines DPA-College of Liberal Arts Kalinga State 
University Dagupan, Tabuk City, $3800 \quad$ Philippines https://www.indianjournals.com/ijor.aspx $?$ target=ijor:ijarmss $\&$ volume $=8 \&$ issue $=5 \&$ arti cle $=021$

Ragandang III, Primitivo C. (2018). Philippines: A Review of the Traditional Conflict Resolution Practices Among Indigenous Cultural Communities https://www.researchgate.net/publication/324911820_Philippines_A_Review_of_the_T raditional_Conflict_Resolution_Practices_Among_Indigenous_Cultural Communities 